\title{
Sesame radiatum Phytoestrogens Stimulate Spermatogenic Activity and Improve Sperm Quality in Adult Male Sprague Dawley Rat Testis
}

\author{
Fitoestrógenos Sesame radiatum Estimulan la Actividad Espermatogénica y Mejoran la Calidad del \\ Esperma en el Testículo de Ratas Sprague Dawley Adulto de Sexo Masculino \\ "Shittu Lukeman, A. J.; "Shittu Remilekun, K.; **Adesite Samson, O.; ${ }^{* * *}$ Ajala, M. Oluwole; ${ }^{* * * *}$ Bankole Munir, A.; **B Benebo A. \\ S.; ${ }^{* * * * *}$ Tayo, A. O.; ${ }^{* * * * * *}$ Ogundipe Olufemi, A. \& Ashiru Oladapo, A.
}

SHITTU, L.A. J.; SHITTU, R. K.; ADESITE, S. O.; AJALA, M. O.; BANKOLE, M.A.; BENEBO, A. S.; TAYO, A. O.; OGUNDIPE, O. A. \& ASHIRU, O. A. Sesame radiatum phytoestrogens stimulate spermatogenic activity and improve sperm quality in adult male Sprague Dawley rat testis. Int. J. Morphol., 26(3):643-652, 2008.

SUMMARY: Increasing concern has been expressed about the declining sperm count of humans and the potential environmental effects of both synthetic and natural estrogenic endocrine disruptors (EEDs) on human reproductive health in the last few decades. However, due to paucity of knowledge, we evaluate the chronic reproductive toxicity of sesame phytoestrogenic lignans on the male Sprague Dawley (SD) rats' testis. Thirty adult male SD rats weighing 150-200g were divided into three groups. Two treated groups received a daily dose of aqueous leaves extract of Sesamum radiatum at $14.0 \mathrm{mg} / \mathrm{kg}$ bw and $28.0 \mathrm{mg} / \mathrm{kg}$ bw respectively via gastric gavage, while equal volume of normal saline was administered to the control group for six weeks. Seminal analysis and hormonal assay study were analyzed using SPSS software and $\mathrm{P}<0.05$ was considered statistically significant. The results showed significant $(\mathrm{P}<0.05)$ body weight gains observed in all the animals with significant $(\mathrm{P}<0.05)$ weight increase in their raw testicular weights compared to control. The relative testicular weight per $100 \mathrm{~g}$ bw was significantly $(\mathrm{P}<0.05)$ higher in control than treated. However, theweight gain was dose related with a reversal in their relative testicular weight. The cauda sperm count including the motility and morphology of the treated were significantly $(\mathrm{P}<0.05)$ higher than control in a dose related manner. In addition, significant $(\mathrm{P}>0.05)$ increases in testosterone and a significant decrease in FSH in the high dose (treated) compared to control. Sesame phytoestrogenic lignans improves spermatozoa quality in a dose related manner.

KEY WORDS: Testis; Sesame leaves; Histopathology; Hormonal assay; Seminal analysis; SD Rats.

\section{INTRODUCTION}

Increasing concern expressed about the declining sperm counts of humans in the last few decades. This is hypothesized to be as a result of the rising incidence of both testicular cancers and subfertility caused by exposure of the developing male embryo to certain potential environmental estrogenic agents that disrupt normal hormonal balance in the body (Sharpe \& Shakkebeak, 1993; Sharpe, 2003; Izegbu et al., 2005; Shittu, 2006).
Recently, one of such agents is phytoestrogens, which have attracted a lot of research interest because of their potential wide range of health benefits. They are estrogenic plant-derived non-steroidal hormone-like phenolic compounds with four broad classes that include isoflavonoids, coumestans, stillbenes and lignans (Adlercreutz et al., 1986; Murkies, 1998). They exist commonly in our local fruits, legumes, foods and dietary supplements.

Department of Anatomy, Lagos State University College of Medicine, Ikeja, Lagos, Nigeria.

* Medical Microbiology Unit, Bolomedics Laboratories, Egbeda, Lagos, Nigeria.

** Department of Morbid Anatomy, Lagos State University College of Medicine/ Lagos State University Teaching Hospital, Ikeja, Lagos Nigeria.

*** Department of Chemical Pathology, College of Medicine/ Lagos State University Teaching Hospital, Ikeja, Lagos Nigeria.

**** Department of Medical Microbiology and Parasitology, College of Medicine, University of Lagos/Lagos University Teaching Hospital, Idi-araba, Lagos, Nigeria.

***** Department of Obstetrics and Gynaecology, Lagos State University College of Medicine/ Lagos State University Teaching Hospital, Ikeja, Lagos Nigeria.

****** Department of Biochemistry, College of Health Sciences, Obafemi Awolowo University, Ile-Ife, Oshun State. 
SHITTU, L. A. J.; SHITTU, R. K.; ADESITE, S. O.; AJALA, M. O.; BANKOLE, M. A.; BENEBO, A. S.; TAYO, A. O.; OGUNDIPE, O. A. \& ASHIRU, O. A. Sesame radiatum phytoestrogens stimulate spermatogenic activity and improve sperm quality in adult male Sprague Dawley rat testis. Int. J. Morphol., 26(3):643-652, 2008.

Similar to endogenous estrogenic structural make up, phytoestrogens tend to mimic or modulate endogenous oestrogenic activity which could either be estrogenic or/and anti-estrogenic depending on their concentration level in the mammalian tissues. These responses are because of their weak binding on the oestrogen receptors- $\mathrm{a}$ and $\mathrm{b}$, with marked varied distribution in the body. However, moderate to high expression of ER a are found in pituitary, kidney, epididymis, and adrenal while, moderate to high expression of ER $b$ are found in prostate, lung, and bladder, with overlapping high expression equally seen in the brain, ovary, testis, and uterus (Shughrue et al., 1996; Kuiper et al., 1997; Kuiper et al., 1998).

Moreover, because they are consumed in large amounts in the diet, the metabolic effects noticed are usually that of antiestrogenic, since, they compete with the much more potent endogenous estradiol for the receptor binding sites, thereby blocking their estrogenic activity (Martin et al., 1978; Whitten \& Naftolin, 1991).

Sesame is a reputed plant in folk medicine in Africa and Asia. It is one of the richest food source of lignans, a major type of phytoestrogens known to man since the dawn of civilization (Thompson et al., 1991) and is now been increasingly incorporated into human diets because of its reported health benefits. However, sesame lignans such as sesamin, episesamin, sesamolin, and sesamol isolated from Sesamum indicum and radiatum seeds among other species are implicated as having certain properties such as antitumorigenic (Hirose et al., 1992), estrogenic and/or antiestrogenic (Collins et al., 1997; Shittu) and antioxidant (Kang et al., 2005; Shittu).

All parts of the plant are useful and consumed locally as a staple food especially the seed, oil and leaves by subsistence farmers in South-West and Middle Belt areas of Nigeria (Akpan-Iwo et al., 2006). This may however account for the high fecundity among the adult male population in these areas (Shittu). In the South-Western Nigeria, decoction of the leaves is used for the treatment of bruised or erupted skins, catarrh and eye pains. In addition, leaves decoction have recently been found to possess antimicrobial properties (Shittu et al., 2006; Bankole Munir et al., 2007; Ahmed et al., 2007, Shittu et al., 2007).

Moreover, estrogen is responsible for maintaining the differentiated epithelial morphology of the male reproductive organs through an unknown mechanism .Thus, estrogen or its receptor is important for normal functioning of the male reproductive tract in numerous species (Hess \& Carnes, 2004).

Most previous studies have evaluated the role of isoflavonoids and other types of phytoestrogens other than sesame lignans. However, due to paucity of knowledge, we aim to evaluate reproductive effect of sesame phytoestrogenic lignans in aqueous extract of Sesame radiatum leaves on the adult male SD rat testis using hormonal assay, seminal analysis and histopathological evidences.

\section{MATERIAL AND METHOD}

Collection of Plant materials: Sesame plants (Sesame radiatum, Schum and Thonn - Pedaliacaea family) were purchased from a vendor in Agege market, Lagos after being identified by Dr. Shittu in May 2005. However, the plant was authenticated by the herbarium section of Forestry Institute of Research ( FRIN) with FHI \# 107513 on the 5th of August, 2005 (Shittu et al., 2006). In addition, voucher specimens were deposited in Botany Departments of University of Ibadan and Lagos State University, respectively.

Preparation of Aqueous Extracts of Sesame leaves. The leaves of the plants were air dried for 2 weeks and powdered. $100 \mathrm{~g}$ of the powdered leaves were added to 1.0 litre of distilled water at a ratio of 1: 10 in a beaker and allowed to boil to boiling temperature after intermittent stirring on a hotplate for one hour. The decoction was filtered into another clean beaker using a white sieve clothing material and the filtrate evaporated at $50{ }^{\circ} \mathrm{C}$ to dryness in a desiccator to produce a black shinning crystal residue form with a yield of $83 \% \mathrm{w} / \mathrm{w}$ of the extract. The crude extract was kept in the refrigerator $\left(4^{\circ} \mathrm{C}\right)$ before being reconstituted and later used for the in-vivo study.

Ether-extracts preparation of sesame leaves for phytochemical assay. The leaves were air-dried and $100 \mathrm{~g}$ of the powdered leaves were extracted with $500 \mathrm{ml}$ of $40 \%$ diethyl ether for $72 \mathrm{~h}$ with Soxhlet equipment using modified method of Alade \& Irobi (1993).

Phytochemical screening using Gas ChromatographyMass Spectral. Gas chromatography of crude ether extract of sesame leaves was performed using a Hewlett Packard GCD system (model 6890 ), equipped with a flame ionization detector and injector MS transfer line temperature maintained at $230^{\circ} \mathrm{C}$ respectively as described in our previous study (Shittu et al., 2006).

Compound identification was accomplished by comparing the GC relative retention times and mass spectra to those of authentic substances analyzed under the same conditions, by their retention indices (RI) and by comparison to reference compound (Shittu et al., 2006). 
SHITTU, L. A. J.; SHITTU, R. K.; ADESITE, S. O.; AJALA, M. O.; BANKOLE, M. A.; BENEBO, A. S.; TAYO, A. O.; OGUNDIPE, O. A. \& ASHIRU, O. A. Sesame radiatum phytoestrogens stimulate spermatogenic activity and improve sperm quality in adult male Sprague Dawley rat testis. Int. J. Morphol., 26(3):643-652, 2008.

Animal. Thirty mature and healthy adult male Sprague Dawley rats weighing 150 to $200 \mathrm{~g}$ were procured from Lagos State University, College of Medicine, Ikeja and housed in a well ventilated wire-wooden cages in the departmental animal house. They were maintained under controlled light schedule (12 hours Light: 12 hours Dark) at room temperature (28oC) and with constant humidity (40-50\%). The animals were allowed to acclimatize for a period of 7 days before treatments. During this period they were fed with standard rat chows/pellets supplied by Pfizer Nigeria Ltd and water ad-libitum. Individual identification of the animal was made by ear tags.

Experimental design. The rats were randomly divided into three groups (A to C) comprising of ten rats each.

The group A served as the control while B and C constituted the treated groups.

The group A animals received equal volume of $0.9 \%$ (w/v) normal saline daily while group B ( high dose group) received aqueous extract of sesame leaves at $28.0 \mathrm{mg} / \mathrm{kg}$ body weight /day.

However, group C (low dose group) animals received doses of $14.0 \mathrm{mg} / \mathrm{kg}$ body weight /day of aqueous extract of sesame leaves. All the doses administered via gastric gavage daily for a period of 6 weeks. All procedures involving animals in this study conformed to the guiding principles for research involving animals as recommended by the Declaration of Helsinki and the Guiding Principles in the Care and Use of Animals (World Medical Association \& American Physiological Society, 2002) and were approved by the Departmental Committee on the Use and Care of Animals.

All animals observed for clinical signs of plant toxicity (such as tremors, weakness, Lethargy, refusal of feeds, weight loss, hair-loss, coma and death) throughout the duration of the experiment.

Animal sacrifice. The rats were anaesthetized at the time of sacrifice using sealed chloroform -soaked cotton wool inhalation jar between 0900 and 1100 hours. This was done the next day after the termination of the whole experiments following over-night fasting of the animals. The weights of the animals were taken weekly and before sacrifice.

Organ Harvest and Tissue processing for Light Microscopy. Both testes were carefully dissected out, trimmed of all fat and blotted dry to remove any blood. The raw testicular weights were noted and volume displaced measured using a $10 \mathrm{ml}$ measuring cylinder. In addition, the sizes (length and width) were recorded by use of a sliding gauge $(\mathrm{d}=0.1)$ before fixation in a freshly prepared $10 \%$ formol saline solution.

We transferred the fixed tissues into graded alcohol and then processed for 17.5 hours in an automated Shandon processor after which they passed through a mixture of equal concentration of xylene. Following clearance in xylene the sections were then infiltrated and embedded in molten paraffin wax. However, prior to embedding, the mounted sections were orientated perpendicular to the long axes of the testes before we ensure cutting with the aid of the rotary microtone. These sections were designated as "vertical sections".

Serial sections of $5 \mu \mathrm{m}$ thickness were cut , floated onto clean slides coated with Mayer's egg albumin for proper cementing of the sections to the slides and were then stained with Haematoxylin and Eosin stains as described in a previous study (Shittu).

Serum Hormonal Assay. Using the procedure enclosed with the kit purchased from Amersham International Plc. (UK), serum testosterone concentration was estimated by ELISA technique as previously described in our study (Shittu, 2006). The inter- and intra-assay coefficients of variation for the Testosterone were $<15 \%$. While, serum FSH estimation was done using RIA techniques as previously described by Shittu.

Cauda Sperm Forward Motility. After anesthetizing the rat, scrotal incision was made to expose the whole testis including the epididymes. The epididymes dissected out and freed from adhering fat and connective tissues using the guidelines of Hamilton.

Spermatozoa expressed out by cutting the distal end of the cauda epididymidal tubule approximately into 1.0$\mathrm{mm}^{3}$ pieces with a sharp razor blade and the spermatozoa with epididymal fluid diluted with physiological saline was placed on a thin glass slide. One hundred spermatozoa taken from each rat were then observed under phase contrast light microscope for forward motility (rate and percentage) (WHO, 1999).

Sperm Count. The method of Zaneveld \& Polakoski (1977) employed to estimate the caudal epididymal spermatozoa count. Aliquots of the sperm suspension were placed on both sides of the new improved Neubauer's hemocytometer and allowed to settle by keeping in a humid chamber for 1 hour. The number of spermatozoa per mililitre in the appropriate squares of the haemocytometer was counted under the phase contrast light microscope at $100 ¥$ magnification. Six counts ( 3 from each side from a single rat) were taken provided the 
difference between the two counts did not exceed $10 \%$ and the average of all the six counts taken as one observation.

Sperm morphology assessment. Caudal sperm were taken from the original dilution for motility and diluted 1:20 with $10 \%$ neutral buffered formalin (Sigma-Aldrich, Oakville, ON, Canada). Briefly, in wet preparations using phasecontrast light microscope at x400 magnification, the sperm cells were categorized as follows: (1) normal head and tail, (2) isolated heads (whether the head was misshapen or not), (3) head- only defects (i.e., misshapen head with normal tail), (4) tail defects (i.e., normal head with abnormal tail or misshapen head with abnormal tail), and (5) fused sperm and was expressed as a percentage of morphologically normal sperm (WHO).

Statistical analysis. The weight data were expressed in Mean + S.D (Standard deviation) while other data were expressed as Mean \pm S.E.M (Standard Error of Mean). Statistical analyses were done by using the student t-test and ANOVA as the case may be with input into SPSS 12 software Microsoft computer (SPSS, Chicago, Illinois). Statistical significance was considered at $\mathrm{P} \leq 0.05$.

\section{RESULTS}

No obvious signs of toxicity such as weakness, lethargy, tremors, refusal of feeds, weight loss, hair-loss, coma and death were seen in any of the animals. However, most of the animals exhibited calmness; improve appetite for food and water and general sense of well-being, all through the duration of the study.

The GC/MS showed the presence of essential oils mainly the carboxylic phenolic groups such as (sesamol, sesamin) and other compounds such as thiazole, pyrroles, disulphide, ketones, fatty acids and aldehyde in the leaves extract. Also, confirmed the presence of trace elements/ minerals, vitamins and steroids such as adrostenedione among others.

Evidence of significant $(\mathrm{P}<0.05)$ body weight gain using one-way ANOVA observed in all the animals. The weight gain observed in the treated groups was dose dependent as seen in Table I.

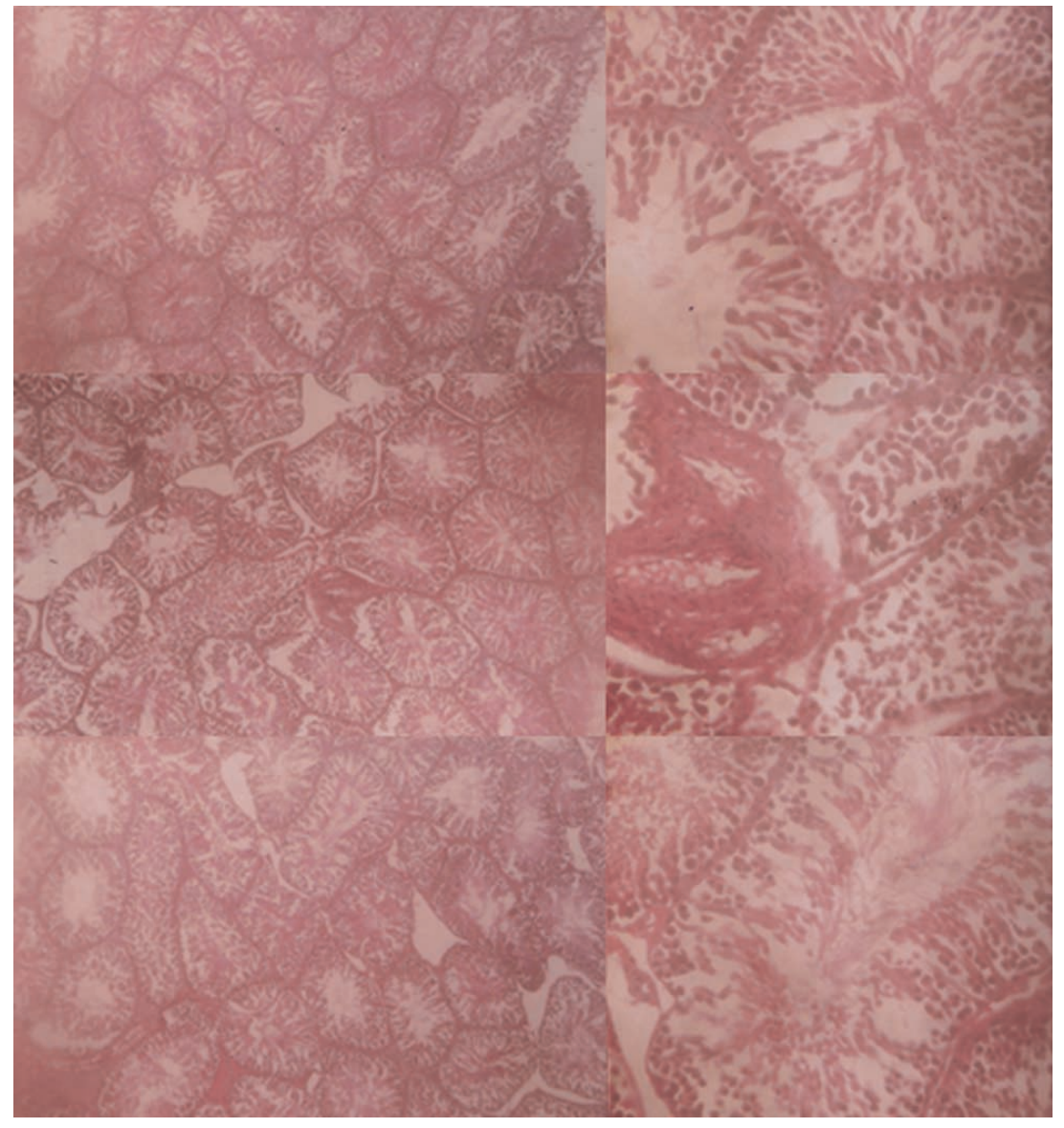

Fig. 1. Showing the photomicrographs of the animals.

The top micrographs- showed control group with numerous seminiferous tubules that are small and more rounded in shape. They are tight and closely packed compared to the treated groups with scanty spermatocytes in their lumens as observed at X 100 and X 400 magnifications.

The middle micrographs -showed the high dose group with evidence of spermatocytes fullness within the varying tubular lumens of different sizes seminiferous tubules. There is evidence of widespread diffuse increased in spermatogenic activity and spermatocytes turnover. Also, numerous elongated seminiferous tubules with widening of the interstitial spaces and increased interstitial activity observed as seen in the X100 and X 400 magnifications.

The lower micrographs- showed similar features like the high dose groups but to a lesser extent as observed at X100 and X 400 magnifications. 
SHITTU, L. A. J.; SHITTU, R. K.; ADESITE, S. O.; AJALA, M. O.; BANKOLE, M. A.; BENEBO, A. S.; TAYO, A. O.; OGUNDIPE, O. A. \& ASHIRU, O. A. Sesame radiatum phytoestrogens stimulate spermatogenic activity and improve sperm quality in adult male Sprague Dawley rat testis. Int. J. Morphol., 26(3):643-652, 2008.

There were significant $(\mathrm{P}<0.05)$ weight changes observed in the raw testicular weights, such that the relative testicular weight per $100 \mathrm{~g}$ bw was significantly $(\mathrm{P}<0.05)$ higher in control than treated. This weight gain was however, more in the high dose than the low dose group except for their relative testicular weight as shown in Table II.

The cauda sperm count was significantly $(\mathrm{P}<0.05)$ higher (that is, about 3.4 fold increments in the high dose) in sesame groups than the control in a dose related manner. In addition, the sperm motility and morphology of the sesame groups (high and low dose) were significantly $(\mathrm{P}<$ $0.05)$ higher than the control in a dose related manner as shown in Table II.

Significant $(\mathrm{P}>0.05)$ increase in testosterone level of the treated group compared to control. Moreover, the low dose testosterone level was also significantly different from the control as shown in table 3. Conversely, there was also significant $(\mathrm{P}>0.05)$ decrease in FSH level in the high dose (treated) group compared to control as seen in Table III.

The histopathological findings on the photomicrographs are as follow: The control group have numerous seminiferous tubules that are small and more rounded in shape. They are tight and closely packed interstitium with few leydig cells and with scanty spermatocytes in their lumens compared to the treated groups as observed at X 100 and X 400 magnifications.

However, the high dose group showed evidence of spermatocytes fullness within the varying tubular lumens of the different sizes seminiferous tubules seen in the photomicrographs. There is evidence of widespread diffused increase in spermatogenic activity and spermatocytes turnover. In addition, numerous elongated seminiferous tubules with widening of their interstitial spaces and increased interstitial activity with more densly stained leydig cells observed as seen in the X100 and X 400 magnifications.

Table I. Summary of body and organ weights of animals. N = 10 rats per group.

\begin{tabular}{lcccc}
\hline GROUP & $\begin{array}{l}\text { Pre-experimental body } \\
\text { weight }(\mathrm{g})(\mathrm{Mean} \pm \mathrm{S} . \mathrm{D})\end{array}$ & $\begin{array}{l}\text { Final body } \\
\text { weight }(\mathrm{g})(\mathrm{Mean} \pm \text { S.D })\end{array}$ & $\begin{array}{l}\text { Raw Testicular weight } \\
(\mathrm{g})(\mathrm{Mean} \pm \text { S.E.M })\end{array}$ & $\begin{array}{l}\text { Relative Testiculo-somatic weight. } \\
\text { Wt/100g bwt })(\text { Mean } \pm \text { SEM })\end{array}$ \\
\hline $\begin{array}{l}\text { GROUP A } \\
\text { (control) }\end{array}$ & $127.3+5.55$ & $185.2+11.05^{*}$ & $0.55+0.03^{*}$ & $0.67+0.01$ \\
$\begin{array}{l}\text { GROUP B (high } \\
\text { dose sesame) }\end{array}$ & $206.2 \pm 6.45$ & $248.2 \pm 14.40^{*}$ & $0.76 \pm 0.01^{*}$ & $0.46 \pm 0.02^{*}$ \\
$\begin{array}{l}\text { GROUP C (low } \\
\text { dose sesame) }\end{array}$ & $186.3 \pm 1.99$ & $219.8 \pm 4.47^{*}$ & $0.57 \pm 0.02^{*}$ & $0.52 \pm 0.02^{*}$ \\
\hline
\end{tabular}

$* \mathrm{P}<0.05$ considered significant statistically.

Table II. Summary of mean sperm parameters.

\begin{tabular}{lccc}
\hline Semen parameters & $\begin{array}{c}\text { Group A } \\
\text { ( control) }\end{array}$ & $\begin{array}{c}\text { Group B } \\
\text { (high dose sesame) }\end{array}$ & $\begin{array}{c}\text { Group C } \\
\text { (low dose sesame) }\end{array}$ \\
\hline Sperm Count $\left(\mathrm{X} 10^{6} \mathrm{~m} / \mathrm{l}\right)$ & $80 \pm 17.6^{*}$ & $269 \pm 55.3^{*}$ & $141 \pm 29.5^{*}$ \\
Sperm motility ( \%) & $174+46.9^{*}$ & $304+27.1^{*}$ & $248+29.4^{*}$ \\
Motility index & $52+9.7^{*}$ & $76+6.8^{*}$ & $62+7.4^{*}$ \\
Morphology ( \% Normal) & $88+1.7^{*}$ & $93+0.7^{*}$ & $93.4+1.4^{*}$ \\
\hline
\end{tabular}

$* \mathrm{P}<0.05$ considered statistically significant.

Table III. Summary of hormonal profile of the animals.

\begin{tabular}{|c|c|c|c|}
\hline Hormones & Group A (Control) & $\begin{array}{c}\text { Group B (High dose } \\
\text { sesame) }\end{array}$ & $\begin{array}{c}\text { Group C ( Low dose } \\
\text { sesame ) }\end{array}$ \\
\hline Testosterone (ng/ml) & $0.8+0.03$ & $0.9+0.2^{*}$ & $0.1+0.0^{*}$ \\
\hline FSH ( I.U ) & $11.0 \pm 2.3^{*}$ & $6.3 \pm 0.6^{*}$ & $2.1 \pm 0.2^{*}$ \\
\hline
\end{tabular}


SHITTU, L. A. J.; SHITTU, R. K.; ADESITE, S. O.; AJALA, M. O.; BANKOLE, M. A.; BENEBO, A. S.; TAYO, A. O.; OGUNDIPE, O. A. \& ASHIRU, O. A. Sesame radiatum phytoestrogens stimulate spermatogenic activity and improve sperm quality in adult male Sprague Dawley rat testis. Int. J. Morphol., 26(3):643-652, 2008.

\section{DISCUSSION}

This is the first study to look at the impact of sesame phytoestrogenic lignans on the male reproductive tracts after extensive literature review. Moreover, there is increasing role of sesame lignans research because of its contribution to medicine and of immense economic value to man. However, sesame being rich in trace elements or minerals, vitamins and antioxidant lignans (phytoestrogens) posses the ability of improving fertility potential of the male reproductive tract but its mechanism of action need to be elucidated in this study.

We know that the beneficial effects derived from the high consumption of fruits and vegetables can influence not only the various metabolic disease conditions in the body (such as diabetes mellitus, obesity, heart diseases and cancer) but also positively impact on one's reproductive life (Shittu et al., 2006, 2007). However, this beneficial effect may not necessary be due to the well-characterized antioxidants that are usually present in the fruits and vegetables, such as beta-carotene, vitamins $\mathrm{C}$ and $\mathrm{E}$ only. But rather to some other antioxidants or non-antioxidant phytochemicals or indeed, by the synergistic/ additive actions of the different compounds that are present in foods (fruits and vegetables) such as alpha-linolenic acid ( poly unsaturated fatty acids), various phenolic compounds (sesamin, sesamol) and fibres, which are also present in sesame leaves for example (Shittu et al., 2006, 2007).

The GC/MS findings of the ether extract were similar to what obtained when the methanolic extract was used such as the presence of palmitic acids, arachidonic/arachidic acid, stearic acid, oleic acid, linoleic acids among others (Bankole et al.). However, the former yielded more unknown compounds and steroids such as adrostenedione among others.

Moreover, exogenous phytoestrogens are generally less potent in their estrogenic activities than the known endogenous estrogenic substances. Hence, environmental exposure to them has been regarded non-harmful, but beneficial (Whitten \& Naftolin) and have constituted the main staple diets in Eastern populations for hundreds of years with no documented toxicity whatsoever (Adlercreutz et al., 1988).

All the animals used in this study, irrespective of their aggressive nature prior to commencement of the experiment exhibited calmness (non-aggressive state) with a general state of well-being observed during the complete experimental period. This may reflect on the positive and neuroprotective effect of some of the active ingredients such as the phytoestrogenic lignans present in the sesame plant on their neuropsychological and neuro-endocrine pathways in the brains of the animals (Chowen et al., 1992; Singer et al., 1996; Diaz-Brinton et al., 1997).

Moreso, aERKO (a estrogen receptor knock out) mice do not display normal sexual behavior and sterile in nature (Biegon et al., 1983; Ogawa et al., 1997; Ogawa et al., 1998). Unlike, the ERb knockout females and males that usually develop normally that is, exhibit normal sexual behavior with reproductive competency in nature. Although the females do exhibit reduced fertility (that is, fewer and smaller litters), most likely due to decreased in ovarian efficiency (Ogawa et al., 1998).

Hence, it appears that ERa, more than ERb, is necessary for the estrogen-mediated regulation of reproductive physiology, including the behavioral components. However, Whitten \& Patisaul (2001) had earlier reported that steroidogenesis and the hypothalamic-pituitary-gonadal axis may appear to be important loci for phytoestrogen actions in the brain.

The sesame -treated rats showed significant body weight gain $(\mathrm{P}<0.05$, using ANOVA), unlike in other studies where no significant difference in the animal body weights were observed (Awoniyi et al., 1997).

However, the relative testicular weight per $100 \mathrm{~g}$ bw difference of the treated groups (high and low doses) was smaller than their respective raw testicular weight in a reverse order compared to the control. This is a reflection of the site of action of the sesame estrogenic lignans, which tend to bind to both estrogen receptors types ( $a$ and $b$ ) present within the testis compared to the ER a seen predominantly in the epididymis (Kuiper et al., 1997) with significant higher weight per $100 \mathrm{~g}$ bw difference compared to the testis. Moreover, estrogen or its receptor is important for normal functioning of the male reproductive tract in numerous species (Hess \& Carnes).

The significantly higher cauda sperm count obtained in the treated groups correlated well with the numerous spermatogonia observed in the seminiferous tubules epithelial of the sesame treated rats compared to the control. Moreover, other authors in their study had concluded that gestational plus lactation exposure and subsequent dietary exposure to genistein have no adverse effects on gametogenic function in male rats. The increase count could be due to increase in spermatocyte which resulted from increase in proliferation of stem cells or increase in spermiogenesis as large masses of 
SHITTU, L. A. J.; SHITTU, R. K.; ADESITE, S. O.; AJALA, M. O.; BANKOLE, M. A.; BENEBO, A. S.; TAYO, A. O.; OGUNDIPE, O. A. \& ASHIRU, O. A. Sesame radiatum phytoestrogens stimulate spermatogenic activity and improve sperm quality in adult male Sprague Dawley rat testis. Int. J. Morphol., 26(3):643-652, 2008.

seminiferous tubules epithelium appeared to be sloughing or bulging into the tubule lumen as observed in the sesame treated groups photomicographs.

The sperm motility and morphology of the sesame groups (high and low dose) were significantly $(\mathrm{P}<0.05)$ higher than the control. This may be attributed to the reactive oxygen species (ROS) and free radical scavenging moiety of sesame lignans as a powerful anti-oxidant with inhibitory effect on lipid perioxidases and other enzymes such as dismutase and carnitine oxidase which inhibit sperm motility and maturation in the epididymis (Hemalatha et al., 2004; Jeng et al., 2005).

Sperm cell membranes have polyunsaturated lipids in their backbone and are easily prone to reactive oxygen species generation from lipid peroxidation effect of Iron induced oxidative stress among others inducers leading to reactive oxygen species formation and free radical injuries to body tissues (Halliwell \& Gutteridge, 1985). However, unlike most other body cells, once the sperm cells are damaged especially in some sperm washing procedure, they cannot undergo repair in the process. These effects are prevented by sesame lignans (Hemalatha et al.).

Sesame lignans have been shown to increase tissue tocopherol levels by inhibition of cytochrome P450 3Adependent n-hydroxylasse pathways of tocopherol catabolism and/or regeneration of oxidized tocopherol, hence potentiating the antioxidants activity of tocols in lipid peroxidation system in-vitro (Hemalatha et al.). This synergism between Vitamin $\mathrm{E}$ and sesame lignans enhance the morphological as well as quality of the sperm produced as evidenced in this present study.

This antioxidative property of the lignans as a phytoestrogens is also corroborated by the neuroprotective function of estrogens in a recent study, where a 24-h pretreatment of cultured primary cortical neurons with 15 $50 \mathrm{~nm} \mathrm{17b-estradiol} \mathrm{led} \mathrm{to} \mathrm{reduction} \mathrm{of} \mathrm{glutamate-induced}$ toxicity, measured by lactate dehydrogenase release. This effect however was blocked by a known estrogen antagonisttamoxifen. Hence, suggesting that estrogen neuroprotection may involve the activation of intracellular ER (Singer et al.).

Sesame phytoestrogenic lignans tend to promote aromatization of $\mathrm{T}$ to estradiol (E2). In the low dose sesame, there is less competition with endogenous E2 for the steroid hormone binding protein carrier. Although, synergism seem to occur at this level between the $\mathrm{T}$ and $\mathrm{E} 2$ to favour spermatogenesis as evidenced in this study.

However, reverse is the case for the high dose, where more E2 is available and compete more with endogenous E2 for the steroid hormone binding protein carrier and with DHT for aromatization to occur in its favour since $\mathrm{T}$ is irreversibly aromatize to $\mathrm{E} 2$ by the action of aromatase enzymes. The low T obtained in the high dose group is not due to destruction of the Leydig cells but a reflection of the complex hormonal interplay at the level of the Hypothalamic-pituitary-testicular axis. Estrogen agonist like clomiphene has been found to decrease the synthesis and/or release of gonadotrophins with the implication of both low serum (Leutenizing Hormone) $\mathrm{LH}$ and testosterone concentration found in male rats (Brown \& Chakraborty, 1992). However, low dose E2 is also require for spermatogenesis as evidence in the present study.

The low T level observed in the low dose sesame group may be attributed to the fact that some of the T were aromatized to estradiol (E2) and/or converted to Dihydrotestosterone (DHT) by the aromatase and reductase enzymes present within the testis or epididymis (Shittu).

Testosterone (T) level in the high dose sesame was significantly $(\mathrm{P}<0.05)$ higher than the control. This is also a reflection of the high interstitial activity from widening of the interstitial space associated with dense stained leydig cells seen on its photomicrographs compared to the tight and closely packed interstitium with fewer and lightly stained leydig cells observed in the control photomicrographs.

Moreover, Huang et al. (1987) demonstrated that as little as $25 \%$ of normal testicular T concentration is sufficient to support all stages of spermatogenesis and that consistency in $\mathrm{T}$ concentration is important for normal spermatogenesis to occur as evidence by the low dose seminiferous tubular lumen with fuller spermatocytes compared to control in the present study.

There is significant $(\mathrm{P}>0.05)$ decrease in FSH level with associated increase in $\mathrm{T}$ level in the high dose (treated) group compared to control as seen in table 3. However, FSH may synergize with testosterone by stimulating the synthesis of the androgen receptor (AR) at receptor level. This is evident from the in-vitro studies carried out in which FSH resulted in a 2-3 fold increase in AR number. In addition, treatment of hypophysectomized rats with $\mathrm{FSH}$ promoted the effect of T spermiogenesis with associated increased testicular content of androgen-binding protein in the testis and epididymis (Marshall et al., 1995; Tony \& Gary, 2001). Moreover, Degen \& Metzler (1987) corroborated by pointing out that there is Estradiol (E2)-induced transactivation of the androgen receptor (AR) in a related study.

In general, aromatase has not been found in rete testis, efferent ductules, epididymis or vas deferens (Hess \& Carnes). However, various reports are found on the epididymal 
SHITTU, L. A. J.; SHITTU, R. K.; ADESITE, S. O.; AJALA, M. O.; BANKOLE, M. A.; BENEBO, A. S.; TAYO, A. O.; OGUNDIPE, O. A. \& ASHIRU, O. A. Sesame radiatum phytoestrogens stimulate spermatogenic activity and improve sperm quality in adult male Sprague Dawley rat testis. Int. J. Morphol., 26(3):643-652, 2008.

presence of aromatase in human efferent ductules and proximal epididymis (Carpino et al., 2004) and cultured rat cells (Wiszniewska, 2002).

However, contrary to speculation that phytoestrogen disrupt male reproductive development through unknown mechanisms. We are able to demonstrate that sesame lignans has positive influence on the male reproductive tract through its binding to the estrogen receptors more especially the ER a than the ER $b$. In addition, modulate the activity of the AR in the testis, thereby ultimately influencing the hypothalamicpituitary -testicular pathway as evidence in this study. This property is enhanced by its anti-oxidative estrogenic ring nature present in sesame lignans (Shittu et al., 2007). Further study is on elucidating this hypothesis.

\section{CONCLUSION}

This study provides evidence that sesame enhance the process of spermatogenesis in a dose related manner through a complex hormonal interplay at the level of the male HPT-axis and ER.

ACKNOWLEDGEMENT. We wish to appreciate the secretariat assistance of Dorcas Adebayo. Staff of the department of Anatomy, LASUCOM, especially Mr Ogunola J. A; staff of Help Laboratory, Maryland, Lagos and Drug Quality Laboratories, LASUTH, Ikeja, Lagos

The authors provided financial supports for this study.

SHITTU, L. A. J.; SHITTU, R. K.; ADESITE, S. O.; AJALA, M. O.; BANKOLE, M. A.; BENEBO, A. S.; TAYO, A. O.; OGUNDIPE, O. A. \& ASHIRU, O. A. Fitoestrógenos Sesame radiatum estimulan la actividad espermatogénica y mejoran la calidad del esperma en el testículo de ratas Sprague Dawley adulto de sexo masculino. Int. J. Morphol., 26(3):653$652,2008$.

RESUMEN: Una mayor preocupación se ha expresado en las últimas décadas por la disminución en la cantidad de espermatozoides de los seres humanos y los posibles efectos ambientales de disruptores endocrinos estrogénicos (DES) sintéticos y naturales sobre la salud reproductiva humana. Sin embargo, debido a la escasez de conocimientos, evaluamos la toxicidad crónica para la reproducción de fitoestrógenos lignanos del sésamo en el testículo de ratas Sprague Dawley (SD) macho. Treinta ratas macho adultas, de un peso de 150-200g se dividieron en tres grupos. Dos grupos de tratamiento recibieron una dosis diaria de extracto acuoso de las hojas Sesamum radiatum de $14,0 \mathrm{mg} / \mathrm{kg}$ de peso corporal y $28,0 \mathrm{mg} / \mathrm{kg}$ de peso corporal, respectivamente, a través de una sonda gástrica, mientras que igual volumen de solución salina normal se administró al grupo control durante seis semanas. El análisis seminal y estudio de ensayo hormonal fueron analizados mediante el software SPSS y $\mathrm{P}<0,05$ fue considerado estadísticamente significativo. Los resultados mostraron significativas $(\mathrm{P}<0,05)$ ganancias de peso corporal observados en todos los animales con un peso significativo $(\mathrm{P}<0.05)$, aumento de peso en su peso testicular bruto en comparación con el control. El relativo peso testicular por $100 \mathrm{~g}$ de peso corporal fue significativamente mayor $(\mathrm{P}<0,05)$ en control que en tratamiento. Sin embargo, el aumento de peso dosis se ha relacionado con un retroceso en su peso relativo testicular. La cantidad de espermatozoides, incluyendo la motilidad y morfología de los que recibieron tratamiento fue significativamente más alto que el control $(\mathrm{P}<0,05)$ en una dosis relacionados. Además, significativo aumento en los niveles de testosterona ( $\mathrm{P}>0,05)$ y una disminución significativa de FSH en la dosis alta (tratados), en comparación con el control. Fitoestrógenos lignanos del sésamo mejoran la calidad de los espermatozoides en una dosis adecuada.

PALABRAS CLAVE: Testículo; Hojas de sesame; Histopatología; Ensayo hormonal; Análisis seminal; Ratas SD.

\section{REFERENCES}

Adlercreutz, H.; Fotsis, T.; Bannwart, C.; Wähälä, K.; Mäkelä, T.; Brunow, G. \& Hase, T. Determination of urinary lignans and phytoestrogen metabolites, potential antiestrogens and anticarcinogens, in urine of women on various habitual diets. J. Steroid Biochem., 25(5b):791-7, 1986.

Adlercreutz, H.; Honjo, H.; Higashi, A.; Fotsis, T.;
Hämäläinen, E.; Hasegawa, T. \& Okada, H. Lignan and phytoestrogens excretion in Japanese consuming traditional diet. Scand. J. Clin. Lab. Invest., 48(190):190, 1988.

Ahmed, T.; Shittu, L. A. J.; Bankole, M. A.; Adesanya, O. A.; Bankole, M. N.; Shittu, R. K. \& Ashiru, O. A. Comparative Antimicrobial Studies Of Selected 
SHITTU, L. A. J.; SHITTU, R. K.; ADESITE, S. O.; AJALA, M. O.; BANKOLE, M. A.; BENEBO, A. S.; TAYO, A. O.; OGUNDIPE, O. A. \& ASHIRU, O. A. Sesame radiatum phytoestrogens stimulate spermatogenic activity and improve sperm quality in adult male Sprague Dawley rat testis. Int. J. Morphol., 26(3):643-652, 2008.

Antibiotics /Antifungal With Crude Extracts Of Sesame Radiatum Against Some Common Pathogenic Microorganisms. Scientific Research And Essays, 4(4):427-33, 2007.

Akpan-Iwo, G.; Idowu, A. A. \& Misari, S. M. Collection and evaluation of sesame (Sesamum spp.) germplasm in Nigeria. IGPR/FAO, 142:59-62, 2006.

Alade, P. I. \& Irobi, O. N. Antimicrobial activities of crude leaf extract of Acalypha wilkensiana. J. Ethanopharmacol., 39:171-4, 1993.

Awoniyi, C. A.; Santulli, R.; Chandrashekar, V.; Schanbacher, B. D. \& Zirkin, B. R. Neonatal exposure to coumestrol, a phytoestrogen, does not alter spermatogenic potential in rats. Endocrinology, 125:1303-9, 1997.

Bankole Munir, A.; Shittu Lukeman, A. J.; Ahmed Titilade, A.; Bankole Marian, N.; Shittu Remilekun, K.; Kpela Terkula \& Ashiru Oladapo, A. Synergistic Antimicrobial Activities of Phytoestrogens In Crude Extracts Of Two Sesame Species Against Some Common Pathogenic Microorganisms. Afr. J. Trad. CAM, 4(4):427-33, 2007.

Biegon, A.; Reches, A.; Snyder, L. \& McEwen, B. S. Serotonergic and noradrenergic receptors in the rat brain: modulation by chronic exposure to ovarian hormones. Life Sci., 32:2015-21, 1983.

Brown, J. L. \& Chakraborty, P. K. Characterization of the effects of clomiphene citrate on reproductive physiology in male rats of various ages. Acta Endocrinol., 118(3):437-3, 1998.

Carpino, A.; Romeo, F. \& Rago, V. Aromatase immunolocalization in human ductuli efferentes and proximal ductus epididymis. J. Anat., 204:217-20, 2004.

Chowen, J. A.; Torres-Aleman, I. \& Garcia-Segura, L. M. Trophic effects of estradiol on fetal rat hypothalamic neurons. Neuroendocrinology, 56:895-901, 1992.

Collins, B. M.; Mclachlan, J. A. \& Arnold, S. The estrogenic and antiestrogenic activities of phytochemicals with the human receptor expressed in yeast. Steroids, 62:365-72, 1997.

Diaz-Brinton, R.; Tran, J.; Proffitt, P. \& Montoya, M. 17bEstradiol enhances the outgrowth and survival of neocortical neurons in culture. Neurochem. Res., 22:1339-51, 1997.
Degen, G. H. \& Metzler, M. Sex hormones and neoplasia: genotoxic effects in short term assays. Arch. Toxicol., 10:264-78, 1987.

Halliwell, B. \& Gutteridge, J. M. The importance of free radicals and catalytic metal ions in human diseases. Mol. Aspects Med., 8(2):89-193, 1985.

Hemalatha, S.; Raghunath, M. \& Ghafoorunissa Dietary sesame oils inhibits iron-induced oxidative stress in rats. Br. J. Nutr., 92(4):581-7, 2004.

Hess, R. A. \& Carnes, K. The role of estrogen in testis and the male reproductive tract: a review and species comparison. Anim. Reprod., 1:5-30, 2004.

Hirose, N.; Doi, F.; Ueki, T.; Akazawa, K.; Chijiiwa, K.; Sugano, M.; Akimoto, K.; Shimizu, S. \& Yamada, H. Suppressive effect of sesamin against 7,12dimethylbenz[a]-anthracene induced rat mammary carcinogenesis. Anticancer Res., 12:1259-65, 1992.

Huang, H. F. S.; Marshall, G. R.; Rosenberg, R. \& Nieschlag, E. Restoration of spermatogenesis by high levels of testosterone in hypophysectomized rats after long-term regression. Acta Endocrinol. (Copenh), 116:433-44, 1987.

Izegbu, M. C.; Ojo, M. O. \& Shittu, L. A. J. Clinicopathological patterns of testicular malignancies in Ilorin, Nigeria-a report of 8 cases. J. Cancer Res. Ther., 1(4):229-31, 2005.

Jeng, K. C. G. \& Hou, R. C. W. Sesamin and Sesamolin: Nature's therapeutic lignans. Current Enzymes Inhibition, 1: 11-20. In: Jeng KCG, Hou RCW. Sesamin and Sesamolin: Nature`s therapeutic lignans. Current Enzymes Inhibition, 1:11-20, 2005.

Kang, M. H.; Kawai, Y.; Naito, M. \& Osawa, T. J. Nutr., 129:1885. In: Jeng, K. C. G. \& Hou, R. C. W. Sesamin and Sesamolin: Nature's therapeutic lignans. Current Enzymes Inhibition, 1:11-20, 2005.

Kuiper, G. G. J. M.; Carlsson, B.; Grandien, K.; Enmark, E.; Haggblad, J.; Nilsson, S. \& Gustafsson, J. Comparison of the ligand binding specificity and transcript tissue distribution of estrogen receptors a and b. Endocrinology, 138:863-70, 1997.

Kuiper, G. G. J. M.; Shughrue, P. J.; Merchenthaler, I. \& Gustafsson, J. A. The estrogen receptor b subtype: a novel mediator of estrogen action in neuroendocrine systems. Front. Neuroendocrinol., 19:253-86, 1998. 
SHITTU, L. A. J.; SHITTU, R. K.; ADESITE, S. O.; AJALA, M. O.; BANKOLE, M. A.; BENEBO, A. S.; TAYO, A. O.; OGUNDIPE, O. A. \& ASHIRU, O. A. Sesame radiatum phytoestrogens stimulate spermatogenic activity and improve sperm quality in adult male Sprague Dawley rat testis. Int. J. Morphol., 26(3):643-652, 2008.

Marshall, G. R. \& Zorub, D. S. Plant TM Follicle-stimulating hormone amplifies the population of differentiated spermatogonia in the hypophysectomized testosteronereplaced adult rhesus monkey (Macaca mulatta). Endocrinology, 136:3504-11, 1995.

Martin, P. M.; Horwitz, K. B.; Ruyan, D. S. \& McGuire, W. L. Phytoestrogen interaction with estrogen receptors in human breast cancer cells. Endocrinology, 103:1860-7, 1978.

Murkies, A. Phytoestrogens-what is the current knowledge? Aust. Fam. Physician, 27(1):S47-51, 1998.

Ogawa, S.; Lubahn, D. B.; Korach, K. S. \& Pfaff, D. W. Behavioral effects of estrogen receptor gene disruption in male mice. Proc. Natl. Differential Acad. Sci. USA, 94:1476-81, 1997.

Ogawa, S.; Washburn, T. F.; Taylor, J.; Lubahn, D. B.; Korach, K. S. \& Pfaff, D. W. Modifications of testosterone-dependent behaviors by estrogen receptora gene disruption in male mice. Endocrinology, 139:5058-69, 1998.

Sharpe, R. M. The 'oestrogen hypothesis'- where do we stand now? Int. J. Androl., 26:2-15, 2003.

Sharpe, R. M. \& Shakkebeak, N. E. Are oestrogens involved in falling sperm counts and disorders of the male reproductive tract? Lancet, 341(8857):1392-5, 1993.

Shittu L. A. J. The effect of the aqueous crude leaves extract of Sesamum radiatum compared to Mesterolone (proviron) on the adult male Sprague Dawley rats testis and epididymis. MSc Dissertation. Lagos State University, College of Medicine, Ikeja, Nigeria, 2006.

Shittu, L. A. J.; Bankole, M. A.; Ahmed, T.; Aile, K.; Akinsanya, M. A.; Bankole, M. N.; Shittu, R. K. \& Ashiru, O. A. Differential antimicrobial activity of the various crude leaves extracts of Sesame radiatum against some common pathogenic micro-organisms. Sci. Res. Essay, 1(3):108-11, 2006.

Shittu, L. A. J.; Bankole, M. A.; Oguntola, J. A.; Ajala, O.; Shittu, R. K.; Ogundipe, O. A.; Bankole, M. N.; Ahmed, T. \& Ashiru, O. A. Sesame Leaves Intake Improve And Increase Epididymal Spermatocytes Reserve In Adult Male Sprague Dawley Rat. Scientific Research and Essays, 2(8):319-24, 2007.
Shughrue, P. J.; Komm, B. \& Merchenthaler, I. The distribution of estrogen receptor-b mRNA in the rat hypothalamus. Steroids, 61:678-81, 1996.

Singer, C. A.; Rogers, K. L.; Stickland, T. M. \& Dorsa, D. M. Estrogen protects primary cortical neurons from glutamate toxicity. Neurosci. Lett., 212:13-6, 1996.

Thompson, L. U.; Robb, P.; Serraino, M. \& Cheung, F. Mammalian lignan production from various foods. Nutr. Cancer, 16:43-52, 1991.

Tony, M. P. \& Gary, R. M. The Functional Significance Of FSH In Spermatogenesis And The Control Of Its Secretion In Male Primates. Endocr. Rev., 22(6):764-86, 2001.

Whitten, P. L. \& Naftolin, F. Effects of a phytoestrogen diet on estrogen-dependent J. Natl. Cancer Inst., 83(8):541$6,1991$.

Whitten, P. L. \& Patisaul, H. B. Cross-species and interassay comparisons of phytoestrogen action. Environ. Health Perspect., 109(1):5-20, 2001.

Wiszniewska, B. Primary culture of the rat epididymal epithelial cells as a source of oestrogen. Andrologia, 34:180-7, 2002.

World Health Organization (WHO). Laboratory manual for the examination of human semen and semen-cervical mucus interaction. $4^{\text {th }}$ ed. Cambridge, University Press, 1999.

World Medical Association; American Physiological Society. Guiding principles for research involving animals and human beings. Am. J. Physiol. Regul. Integr. Comp. Physiol., 283(2):R281-3, 2002.

Zaneveld, L. J. D. \& Polakoski, K. L. Collection and physical examination of the ejaculate. In: Techniques of Human Andrology. Hafez, E. S. E. (Ed). Amsterdam, North Holland Biomedical Press, 1977. pp.147-56.

Correspondence to:

Dr. Shittu Lukeman A. J

Reproductive Endocrinology Unit,

Department of Anatomy,

Lagos State University College of Medicine,

P.O.Box 9987, Ikeja

NIGERIA

E-mail: drlukemanjoseph@yahoo.com

Received: $30-10-2007$

Accepted: 12-04-2008 